\title{
PRODUCTION OF ENERGY FROM WATER FLOW OUTPUT IN FISH TANK
}

\author{
MUNIANDY SIVASAMBUA AND NIK AZIZ BIN NIK ALI ${ }^{\mathrm{B} *}$ \\ a,b Faculty of Fisheries and Food Science, Universiti Malaysia Terengganu, Kuala Nerus, Terengganu, Malaysia \\ * Corresponding author: nikaziz@umt.edu.my
}

\begin{abstract}
Nowadays, the world is confronting the increasing energy demand, reduction of emissions and security of energy supply. The high energy demand leads to a severe problem, and we need to reduce the usage of non-renewable energy to avoid adverse climate change. Thus, renewable energy is an important role obtained from the natural environment and can be replenished naturally from those sources without environmental degradation. Water energy is one of the most promising renewable energy sources today, especially in the aquaculture industry. Hydropower played a vital role in producing large scale power and electricity. This study was set up to determine the electrical energy output depending on the different sizes and shapes of tanks. It is also to measure the water flow rate based on different size and shape tanks. Besides, the Pelton type of water turbine generator micro-hydroelectric DC $12 \mathrm{~V}$ output was used in this experiment. Two types of tanks (rectangular and circular) with three different sizes ( 0.5 ton, 1.0 ton and 2.0 ton) were tested to measure high value of output energy $(\mathrm{V})$ and flow rate $\left(\mathrm{m}^{3} / \mathrm{s}\right)$ by using clear water and wastewater. The result significantly shows that the circular tank had a higher water flow rate and output energy than the rectangular tank due to higher gravitational force, where the outlet placed in the middle and edge of the tank, respectively. The finding of this study benefits the aquaculture industry, where it introduced an alternative and cheaper method of reusing wastewater, reducing the cost maintenances and enhancing the profit of the business.
\end{abstract}

Keywords: Renewable energy, water energy, aquaculture, voltage, and flow rate

\section{Introduction}

Energy is an essential component in our daily life including agriculture, telecommunication, industrial activities and transportation that influence the economic growth as well as being significant in explaining the Industrial Revolution 4.0 (Thank et al., 2012; Allen, 2009). Nowadays, the human had created a various mechanism of energy production. The development of the economy in Malaysia is based on a continuous supply of energy (Bai et al., 2016). Consequently, it infers that any conservation policies or shock to energy supply will have an adverse effect on economic growth, which means that economic growth is dependent on electricity consumption (Quispe et al., 2017). Energy consumption plays a very significant role in economic growth and socio-economic development in developing countries (Masuduzzaman, 2013). Thus, energy is categorized into two categories which are renewable energy and non-renewable energy. According to Renewable Energy Act 2011, renewable energy means energy can be obtained naturally from the environment and non-depleting the indigenous resources. There are various ways to generate energy to produce electricity such as wind, solar, water, geothermal and biomass as shown in Table 1. Besides, nonrenewable energy can also be referred to as natural resources that cannot be regenerated and can only be used once in a lifetime, for example, charcoal, oil, natural gas and nuclear. 
Table 1: Electricity generations from renewable energy (Dragu et al., 2001).

\begin{tabular}{lc}
\hline Methods of Power Generation & $\begin{array}{c}\text { Proportion of } \\
\text { Renewable }\end{array}$ \\
Large hydro $(>10 \mathrm{MW})$ & $86 \%$ \\
Small hydro $(<10 \mathrm{MW})$ & $8.3 \%$ \\
Wind and solar & $0.6 \%$ \\
Geothermal & $1.6 \%$ \\
Biomass & $3.5 \%$ \\
\hline
\end{tabular}

Rakob (2010) points out that Malaysia heavily depends on hydropower, which is the most promising renewable energy for the electricity generation sector. Hydropower or hydroelectricity known as water energy renewable which is the clean and eco-friendly source of power generation. Now, hydropower played a significant role in producing large-scale power and electricity (Prado et al., 2016; Bartle, 2002) with a substantial amount of hydropower resources and potential hydropower around 29,000 MW (Leo-Moggie, 2002). According to Delucchi and Jacobson (2013), the primary benefit of hydropower is meager in operating and maintenance costs and a high level of reliability and efficiency. Hydropower is a power that is derived from moving water through a turbine, which turns a generator and produces electricity (Khurana \& Kumar, 2011; Aziz \& Azli, 2018). Castalia (2003) and Sritram (2015), mentioned that the amount of electricity could be produced depends on the quantity of water passing through a turbine, speed of turbine rotation and the height from which the water 'falls' (head). The greater the flow and the head, the more electricity will be produced. Hydroelectricity contributes around $2.8 \%$ (2000 MW) of Malaysia's total electricity requirements and providing $6 \%$ of world energy supply (Pimentel, 2008). The oil and gas will reduce in a few years. Therefore, it is so important to find any possible ways to produce electricity, which may decrease oil and gas usage.

In terms of aquaculture field, water energy is important with viable results and particularly when utilized in the extensive size of the aquaculture project (Skoglund et al., 2010). This is an efficient and economical way to produce electricity due to low maintenance costs. By reusing the effluent produce from the fish tank, it can be used to generate electricity (Walker et al., 2012). At the same time, it will help the farmers to increase the production profit and also reduce the maintenance cost such as utility bills. Finally, the Pelton type of turbine was used to produce electrical power through clean and wastewater with $60 \%$ to $84 \%$ efficiency in this project. The speed at which a Pelton turbine rotates will be determined by both the flow rate of water directed into its buckets and the load into which it is feeding. If the load falls, the turbine will speed up by controlled the flowthrough from nozzles (Cobb \& Sharp, 2013; Trumbo et al., 2014). This study was carried out with two significant objectives, which measured the water flow rate and the electrical energy (voltage) output based on different shapes and sizes of tanks.

\section{Materials and Methods}

\section{Materials and Apparatus}

There were three phases of method used in this project. In this phase, the equipment and instrument used were Polyvinylchloride (PVC) pipe, two types of tank, which are circular and rectangular taken from Universiti Malaysia Terengganu's PPSPA freshwater hatchery. Besides, the Pelton turbines type of turbine was design as portable in this project as shown in Figure 1. According to Cobb and Sharp (2013) and Trumbo et al. (2014), investigate that its capable of achieving up to $60 \%-84 \%$ efficiency and output performance depends on the percent of actual flow to design flow. Clean water, wastewater, multimeter and stopwatch are essential instruments in this project.

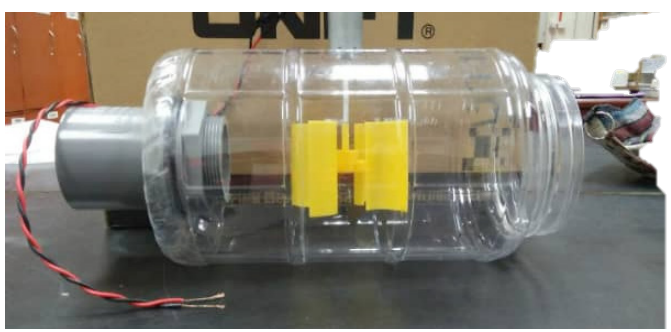

Figure 1: Portable turbine (Pelton type) 


\section{Experimental Design and Layout}

The second phase of this project was an experimental design. This phase was related with the first objective which measured the water flow rate based on the shape of the tank with different sizes of tanks. Each shape of the tank had three size tanks with a different density, which were 0.5 ton, 1.0 ton and 2.0 ton. Thus, the six tanks were prepared by filled wastewater and clean water as control with different. The size of the tanks was shown clearly with the measurement in Figure 2.
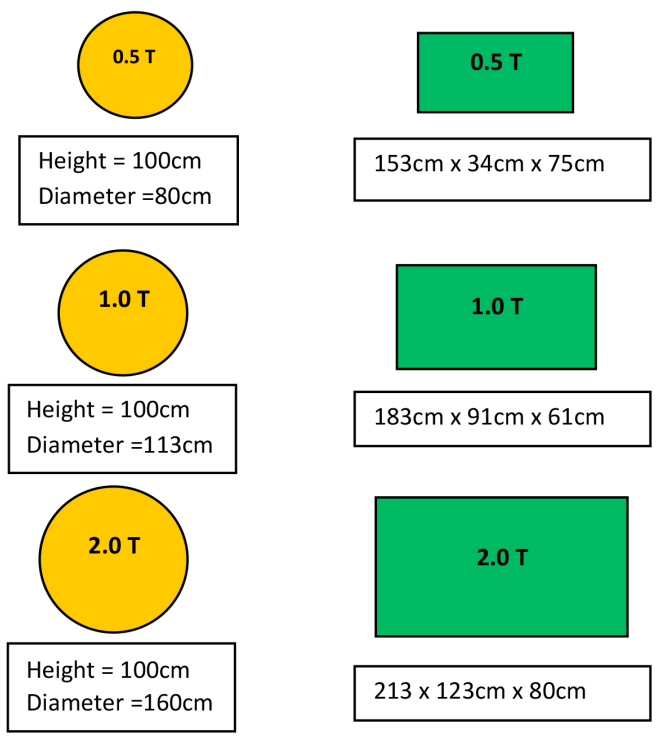

Figure 2: Rectangular and circular tank with different size of tanks

Firstly, the equipment and instrument were set up as shown in Figure 3. As the water flows in a downward direction from the tank (outlet), gravity will produce pressure in the pipeline that is usually relieved by pressure-reducing valves. The stopwatch was started once the valve is open (outlet). Thus, the velocity of water flow was calculated by using equation (1) below. The clean water and wastewater were run thrice to an obtained average value.

Where,

$$
\mathrm{Q}=\mathrm{A} * \mathrm{~V}
$$

$$
\begin{aligned}
& \mathrm{Q}=\text { water flow }\left(1 / \mathrm{min}, 1 / \mathrm{s}, \mathrm{m}^{3} / \mathrm{s}, \mathrm{cm}^{3} / \mathrm{s}\right) \\
& \mathrm{V}=\text { water velocity }(\mathrm{m} / \mathrm{s})
\end{aligned}
$$

A = cross-sectional area of where the water is flowing. For full pipes, the cross sectional area will be the interior crosssection of the pipe

(Lekang, 2007)

The velocity of flow rate was calculated and recorded in different sizes and shapes and the diagram as shown in Figure 2. At the same time, the second objective was achieved, where the force exerted by the water flow on the blades causes the turbine to rotate. The rotation of the turbine is converted into electricity by a generator. Thus, the average value of electrical energy production (voltage) from water flow was analyzed and recorded.

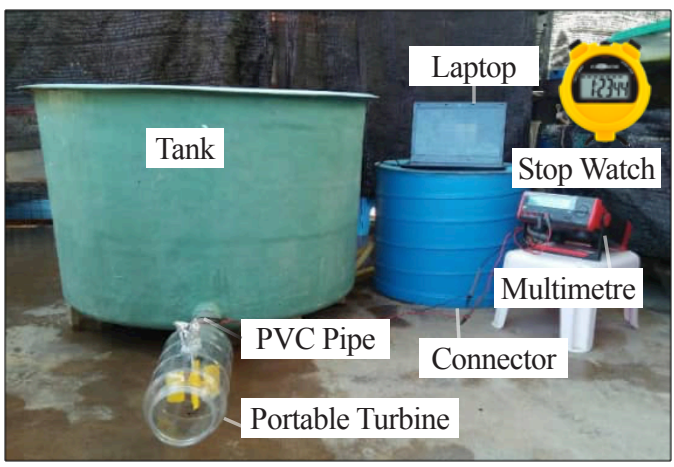

Figure 3: Experiment design of the project

\section{Statistical Analysis}

In this experiment, all the data were taken and subjected to the normality test. The data were analyzed by the correlation between different sizes and shapes of tanks and voltage produced from the water flow. The normality test was tested using the Shapiro-Wilk test to determine the normality distribution of the water sample. Mean of the water treatment tested for significant difference by two-way ANOVA followed Tukey's post-hoc test by using the latest version of the SPSS Software Version 23 (Glover \& Mitchell, 2004; Laerdsstatistics, 2018). The data presented through text, figures and tables are mean \pm standard deviation and statistical significance for all statistical test were set at $\mathrm{p}<0.05$. 


\section{Results and Discussion}

\section{Reading Descriptive}

The voltage and flow rate reading for each shape with different sizes of the tank is shown in Table
2. For this study, two-way ANOVA and Tukey's test were carried out to determine whether there was a statistically significant difference $(\mathrm{p}<0.05)$ with mean \pm standard deviation, where standard deviation represented as error bars.

Table 2: The voltage and flow rate reading for each shape with different size of the tank

\begin{tabular}{|c|c|c|c|c|c|c|c|c|}
\hline \multirow{2}{*}{\multicolumn{2}{|c|}{0.5 ton }} & \multicolumn{3}{|c|}{ Rectangular Tank } & \multicolumn{3}{|c|}{ Circular Tank } & \multirow{2}{*}{$P$ value } \\
\hline & & 1.0 ton & 2.0 ton & 0.5 ton & 1.0 ton & 2.0 ton & & \\
\hline \multirow{2}{*}{$\begin{array}{l}\text { Clean } \\
\text { water }\end{array}$} & $\begin{array}{l}\text { Voltage } \\
\text { (V) }\end{array}$ & $0.242 \pm 0.114^{\mathrm{a}}$ & $0.422 \pm 0.225^{b}$ & $0.594 \pm 0.306^{c}$ & $0.259 \pm 0.115^{a}$ & $0.469 \pm 0.233^{b}$ & $0.635 \pm 0.325^{c}$ & $4.48 \mathrm{E}-08$ \\
\hline & $\begin{array}{l}\text { Flow rate } \\
\left(\mathrm{cm}^{3} / \mathrm{s}\right)\end{array}$ & $1188.62 \pm 7.12^{\mathrm{a}}$ & $1580.65 \pm 10.08^{b}$ & $2383.83 \pm 12.42^{\mathrm{c}}$ & $1208.78 \pm 11.78^{a}$ & $1601.75 \pm 10.38^{b}$ & $2465 \pm 7.64^{c}$ & $3.10 \mathrm{E}-22$ \\
\hline \multirow{2}{*}{$\begin{array}{l}\text { Waste } \\
\text { water }\end{array}$} & $\begin{array}{l}\text { Voltage } \\
\text { (V) }\end{array}$ & $0.229 \pm 0.119^{\mathrm{a}}$ & $0.417 \pm 0.240^{\mathrm{b}}$ & $0.590 \pm 0.288^{\mathrm{c}}$ & $0.245 \pm 0.117^{a}$ & $0.460 \pm 0.261^{b}$ & $0.602 \pm 0.329^{c}$ & $3.96 \mathrm{E}-08$ \\
\hline & $\begin{array}{c}\text { Flow rate } \\
\left(\mathrm{cm}^{3} / \mathrm{s}\right)\end{array}$ & $1129.63 \pm 14.07^{a}$ & $1509.15 \pm 14.83^{b}$ & $2260.00 \pm 20.04^{c}$ & $1160.13 \pm 8.06^{\mathrm{a}}$ & $1534.55 \pm 7.18^{b}$ & $2375.33 \pm 10.18^{c}$ & $1.28 \mathrm{E}-20$ \\
\hline
\end{tabular}

\section{Water Flow Rate Reading}

Flow rate reading for clean water and wastewater in a rectangular tank based on size

The graph was plotted using flow rate $\left(\mathrm{cm}^{3} / \mathrm{s}\right)$ of different water treatments against a different size of tanks. From the graph, 2.0 ton have the optimum water flow rate value compared to 0.5 ton and 1.0 ton. The flow rate in 0.5 ton was $1188.62 \pm 7.12 \mathrm{~cm}^{3} / \mathrm{s}$ in clean water and $1129.63 \pm 14.07 \mathrm{~cm}^{3} / \mathrm{s}$ in wastewater followed by 1.0 ton with $1580.65 \pm 10.08 \mathrm{~cm}^{3} / \mathrm{s}$ in clean water and $1509.15 \pm 14.83 \mathrm{~cm}^{3} / \mathrm{s}$ in wastewater. The highest water flow rate value of clean and wastewater was for 2.0 ton were $2383.83 \pm 12.42$ $\mathrm{cm}^{3} / \mathrm{s}$ and $2260 \pm 20.04 \mathrm{~cm}^{3} / \mathrm{s}$ respectively. It showed that there is a significant $(\mathrm{p}<0.05)$ between both water treatments based on the size of the tank.

Water flow rate reading for clean water and wastewater in the circular tank based on size

The total reading of water flow rate in different size tank of circular shape tank for each treatment is shown below in Figure 5. The reading of the water flow rate for both water treatment was significantly different $(\mathrm{p}<0.05)$ based on the size of the tank. 2.0 ton has the highest and optimum water flow rate value compared to other tank sizes. The result showed the water flow rate in 2.0 ton were $2465 \pm 7.64 \mathrm{~cm}^{3} / \mathrm{s}$ in clean water and $2375.33 \pm 10.18 \mathrm{~cm}^{3} / \mathrm{s}$ in wastewater, this followed by 1.0 ton with $1601.75 \pm 10.38 \mathrm{~cm}^{3} / \mathrm{s}$ in clean water and $1534.55 \pm 7.18 \mathrm{~cm}^{3} / \mathrm{s}$ in wastewater. However, 0.5 ton had the lowest water flow rate reading of clean and wastewater in circular, where $1208.78 \pm 11.78 \mathrm{~cm}^{3} / \mathrm{s}$ and $1160.13 \pm 8.06 \mathrm{~cm}^{3} / \mathrm{s}$ respectively.

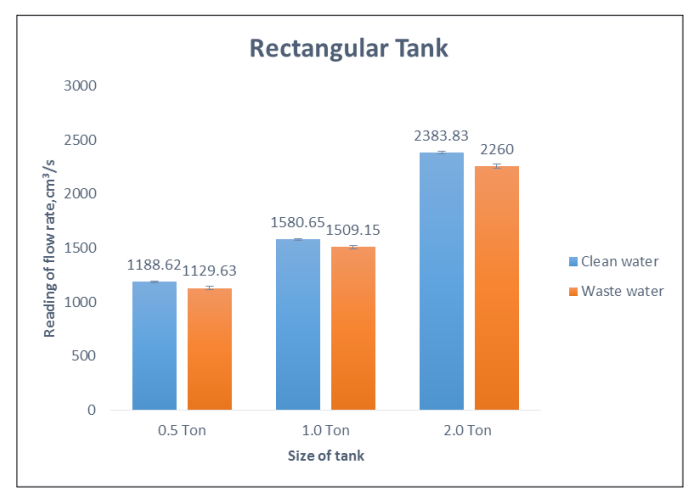

Figure 4: Flow rate reading for clean water and wastewater in a rectangular tank based on size 


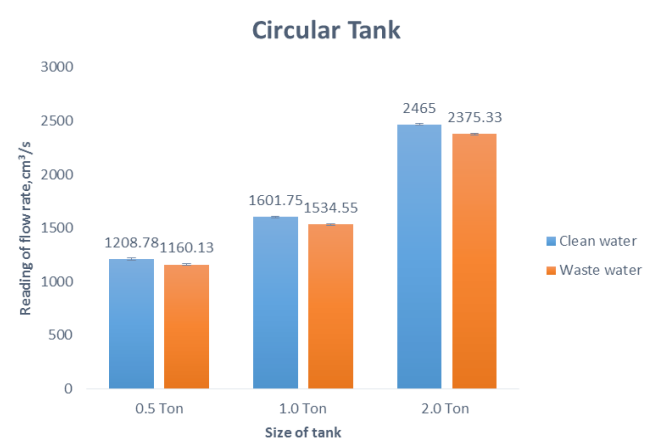

Figure 5: Water flow rate reading for clean water and wastewater in a circular tank based on size.

\section{Water flow rate reading for clean water and wastewater based on the shape of tanks}

Figure 6 showed the total water flow reading of different water treatments based on the shape of the tank with three different sizes of tanks. From this figure, it can be clearly observed that the clean water treatment in the both shapes of the tank with three different sizes showed the highest reading of water flow rate compared to wastewater at $(\mathrm{p}<0.05)$ significance level. The result showed the flow rate of clean water in the rectangular and circular tank of 0.5 ton were $1188.62 \pm 7.12 \mathrm{~cm}^{3} / \mathrm{s}$ and $1208.78 \pm 11.78$ $\mathrm{cm}^{3} / \mathrm{s}$ respectively, this followed by 1.0 ton with $1580.65 \pm 10.08 \mathrm{~cm}^{3} / \mathrm{s}$ in rectangular and $1601.75 \pm 10.38 \mathrm{~cm}^{3} / \mathrm{s}$ in a circular. For 2.0 ton, the highest water flow rate reading of clean water in rectangular and circular were $2383.83 \pm 12.42$ $\mathrm{cm}^{3} / \mathrm{s}$ and $2465 \pm 7.64 \mathrm{~cm}^{3} / \mathrm{s}$, respectively. Based on the graph, the water flow rate of wastewater in the rectangular and circular tank of 0.5 ton were $1129.63 \pm 14.07 \mathrm{~cm}^{3} / \mathrm{s}$ and $1160.13 \pm 8.06$ $\mathrm{cm}^{3} / \mathrm{s}$ respectively, meanwhile, 1.0 ton were with $1509.15 \pm 14.83 \mathrm{~cm}^{3} / \mathrm{s}$ in rectangular and $1534.55 \pm 7.18 \mathrm{~cm}^{3} / \mathrm{s}$ in circular. The highest water flow rate reading of wastewater was recorded in 2.0 ton, where $2260 \pm 20.04 \mathrm{~cm}^{3} / \mathrm{s}$ in rectangular and $2375.33 \pm 10.18 \mathrm{~cm}^{3} / \mathrm{s}$ in a circular.

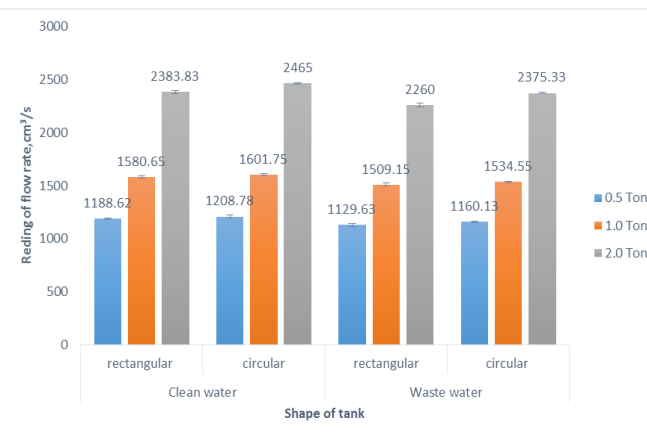

Figure 6: The water flow rate reading of different water treatments based on the shape of the tank with different sizes

\section{Voltage Reading}

\section{Voltage reading for clean water and wastewater in a rectangular tank based on size}

The graph was plotted using voltage reading (V) of different water treatment against a different size of tanks shown below. From the graph, 2.0 ton has the highest voltage value compared to 0.5 ton and 1.0 ton. The voltage in 2.0 ton was $0.594 \pm 0.306 \mathrm{~V}$ in clean water and $0.590 \pm 0.28 \mathrm{~V}$ in wastewater followed by 1.0 ton with $0.422 \pm 0.225 \mathrm{~V}$ in clean water and $0.417 \pm 0.240 \mathrm{~V}$ in wastewater. The least voltage value of clean and wastewater was in 0.5 ton with $0.242 \pm 0.114 \mathrm{~V}$ and $0.229 \pm 0.119 \mathrm{~V}$, respectively. It showed that there is a significant $(p<0.05)$ between both water treatments based on the size of the tank.

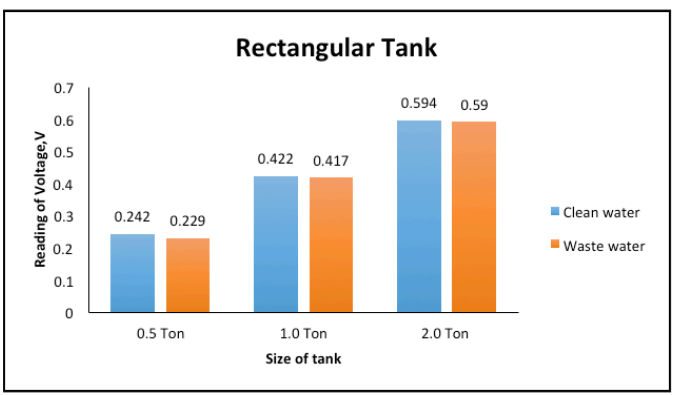

Figure 7: Voltage reading for clean water and wastewater in a rectangular tank based on size 
Voltage reading for clean water and wastewater in the circular tank based on size

From the graph, it was clearly shown that the reading of voltage both water treatments was significantly different $(\mathrm{p}<0.05)$ based on the size of the tank. As shown in Figure 8, the 2.0 ton has the highest and optimum voltage value compared to other sizes. The result showed the voltage in 2.0 ton were $0.635 \pm 0.325 \mathrm{~V}$ in clean water and $0.602 \pm 0.329 \mathrm{~V}$ in wastewater followed by 1.0 ton with $0.469 \pm 0.233 \mathrm{~V}$ in clean water and $0.460 \pm 0.261 \mathrm{~V}$ in wastewater. Meanwhile, 0.5 ton had the lowest voltage reading in clean water and wastewater, where $0.259 \pm 0.115 \mathrm{~V}$ and $0.245 \pm 0.117 \mathrm{~V}$ respectively.

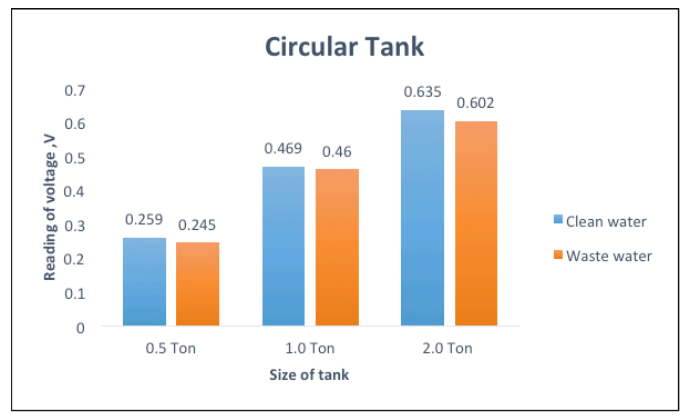

Figure 8: Voltage reading for clean water and wastewater in a rectangular tank based on size

\section{Voltage reading for clean water and wastewater based on the shape of tanks with different size}

Figure 9 showed the total voltage reading of different water treatments based on the shape of the tank with three different sizes of tanks. From this figure, it can be clearly observed that the clean water treatment in both shapes of the tank with three different sizes showed the highest voltage reading compared to wastewater at $(p<0.05)$ significance level. The result showed the voltage of clean water in the rectangular and circular tank of 0.5 ton were $0.242 \pm 0.114 \mathrm{~V}$ and $0.259 \pm 0.115 \mathrm{~V}$ respectively, this followed by 1.0 ton with $0.422 \pm 0.225 \mathrm{~V}$ in rectangular and $0.469 \pm 0.233 \mathrm{~V}$ in circular. For 2.0 ton, the optimum voltage reading of clean water in rectangular and circular was $0.594 \pm 0.306 \mathrm{~V}$ and $0.635 \pm 0.325 \mathrm{~V}$, respectively. Based on the graph, the voltage of wastewater in the rectangular and circular tank of 0.5 ton were $0.229 \pm 0.119 \mathrm{~V}$ and $0.245 \pm 0.117 \mathrm{~V}$ respectively, meanwhile, 1.0 ton were with $0.417 \pm 0.240 \mathrm{~V}$ in rectangular and $0.460 \pm 0.261 \mathrm{~V}$ in circular. The highest voltage reading of wastewater was recorded in 2.0 ton, where $0.590 \pm 0.288 \mathrm{~V}$ in the rectangular tank and $0.602 \pm 0.329 \mathrm{~V}$ in a circular tank.

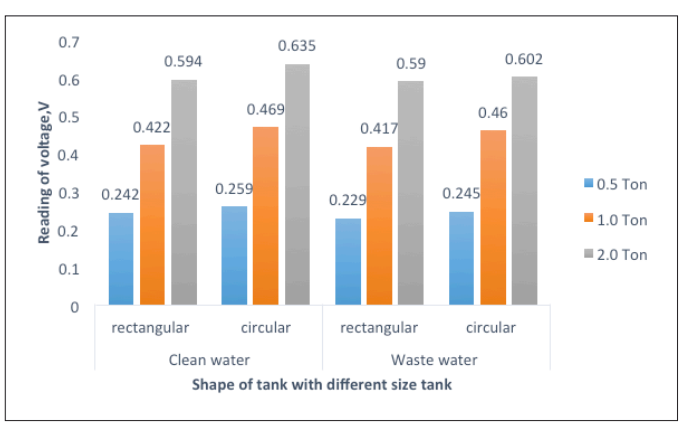

Figure 9: The voltage reading of different water treatments based on the shape of the tank with different sizes

Energy is one of the prime driving force for the socio-economic development of a country (Huda et al., 2014). According to Hossain et al. (2018), round $81.1 \%$ and $80.1 \%$ of the total world primary energy were produced from the burning of fossil fuels respectively in 2014 and 2015. The consequence of this result showed that global greenhouse gas emission is increasing gradually and depleting natural resources. Thus, most countries in the world are now moving towards renewable and environmentally friendly energy resources for electricity generation, especially Malaysia. The best alternative method to generate electricity is hydropower, where it is a clean and cheap source of electricity (Mondal et al., 2014; Iliadis $\&$ Gnansounou, 2016). For the aquaculture field, energy consumption is focused on electrical energy for running the aquaculture system like aeration, filters, circulating and replacing the water in the tank (Neori et al., 2004). Thus, the production of electricity from water flow in the fish tank was showed significant for the reading of voltage and flow rate in three different sizes of tank based on the shape of the tank.

Masaló Llorà (2008) pointed out that the 
geometry of a circular tank is very common in aquaculture because it gives a more homogeneous distribution of dissolved oxygen and metabolites, high stable flow patterns and better self-cleaning features compared to the rectangular tank. The water flow rate also wholly dependent on gravity, where the water flow in the circular tank flows through the outlet in circular motion compared to the rectangular tank. Thus, the water flow rate in circular thank higher than rectangular and at the same time produce a high range of voltage. Bigger the size of the tank, higher the water flow rate recorded compare to the small size of the tank. Moreover, it is clearly seen that clean water recoded higher average voltage compared to wastewater. This can be justified by recent studies, in which wastewater contains high organic and inorganic matters in a fish tank (Camera-Roda et al., 2019). Organic and inorganic matters such as feces, debris, nutrients, suspended solids, and microbial activity. For instance, microbial activity is affected by many factors, likewise, $\mathrm{pH}$ of wastewater, operation condition, and viscosity which in turn influence the production of voltage in wastewater (Wang et al., 2008; Rathour et al., 2019; Shah et al., 2019). This may cause the water flow discharge from the fish tank slower and generated low voltage compared to clean water.

Besides, the average voltage output of a circular shape tank with three different sizes in clean water and wastewater was higher than the rectangular tank as shown in Figure 9. According to Moran (2018) stated that the outlet of any size of the circular tank must be standardized at center and rectangular at the edge of the tank due to center of gravity. The water will drain towards the lowest point in a tank. The smaller the low point, the more efficient the outflow of water. In addition, the wastewater had low voltage than clean water between shape and sizes tank. This is because the effluent contains debris, uneaten feed and algae that might be stuck during the outflow of water. Thus, circular is the best and efficient shape that produced a large amount of voltage in the fish tank.

\section{Conclusion}

In conclusion, the research entitled production of energy from water flow in the fish tank had been completed. The objectives of this experiment were achieved by measured the water flow rate and energy output (voltage) based on the shape of the tank with different tank sizes. The result of the experiment showed that clean water has the highest voltage and water flow rate value than wastewater between the shapes of the tank with different size of the tank. The circular fish tank has the highest value compared to the rectangular fish tank with $0.635 \pm 0.325^{\mathrm{c}}$ and $2375.33 \pm 10.18^{\mathrm{c}}$ respectively. Moreover, the bigger the size of the fish tank, the higher the energy output recorded because of cleaner and wastewater discard from the outlet. Thus, the wastewater that discards the fish tank can be utilized to generated electricity in the aquaculture sector. Other than that, this concept can be used in an inlet and outlet of the Recirculating Aquaculture System (RAS) tank to create more and efficient energy. For future studies, some improvements and suggestions can be done to the experiment on the production of electricity by using renewable energy. For instance, using a high technology digital multimeter to record the voltage value specifically. The next recommendation is to use a flow meter to record the water flow rate digitally, which can minimize the possible errors in obtaining raw data. Another suggestion that might be useful is choosing of the turbine. A high technology turbine can produce efficient voltage to produce electricity.

\section{Acknowledegments}

The author would like to express appreciation to the Faculty of Fisheries and Food Science, Universiti Malaysia Terengganu for the provision of research facilities and technical supports throughout the execution of this final year project. 


\section{References}

Allen, R. C. (2009). The British Industrial Revolution in Global Perspective. Cambridge: Cambridge University Press.

Aziz, P. D. A., and Azli, A. (2018). Development on Micro Hydro Power Generator Design Using Rainwater. Journal of Engineering Technology, 6, 6-9.

Bai, G., Fleck, B., and Zuo, M. J. (2016). A stochastic power curve for wind turbines with reduced variability using conditional copula. Wind Energy, 19(8), 1519-1534.

Bartle A.,(2002) Hydropower potential and development activities. Energy Policy 2002; 30(14):1231-9

Camera-Roda, G., Loddo, V., Palmisano, L., and Parrino, F. (2019). Photocatalytic ozonation for a sustainable aquaculture: a longterm test in a seawater aquarium. Applied Catalysis B: Environmental.

Castaldi, Duane, Eric Chastain, Morgan Windram, and Lauren Zytinck. A Study of Hydroelectric Power: From Global to Local Application. Rep. 2003. Centre for Advanced Studies and Experience, Pennsylvania State University, Print.

Cobb, B. R., and Sharp, K. V. (2013). Impulse (Turgo and Pelton) turbine performance characteristics and their impact on picohydro installations. Renewable Energy, 50, 959-964.

Delucchi, M., and Jacobson, M.Z 2013. Providing all global energy with wind, water, and solar power. Energy Policy, 39(3): 1170-1190

Dragu, C., Sels, T., and Belmans, R. (2001). Small hydro power-state of the art and applications. In Proceedings of International conference Power Generation and sustainable development (AIM) (pp. 265-270).

Glover, T., and Mitchell, K., (2004). Introduction to Biostatistics. New York, NY: McGrawHill Education Europe.
Hossain, M., Huda, A. S. N., Mekhilef, S., Seyedmahmoudian, M., Horan, B., Stojcevski, A., and Ahmed, M. (2018). A state-of-the-art review of hydropower in Malaysia as renewable energy: Current status and future prospects. Energy strategy reviews, 22, 426-437.

Huda, A. S. N., Mekhilef, S., and Ahsan, A. (2014). Biomass energy in Bangladesh: Current status and prospects. Renewable and Sustainable Energy Reviews, 30, 504517.

Iliadis, N. A., and Gnansounou, E. (2016). Development of the methodology for the evaluation of a hydro-pumped storage power plant: Swiss case study. Energy Strategy Reviews, 9, 8-17.

Khurana, S., and Kumar, A. (2011). Small hydro power-A review. International Journal of Thermal Technologies, 1(1), 107-110.

Laerds Statistics. (2018). Available from https:// statistics.laerd.com (Accessed on 18 March 2018)

Lekang, O. (2007). Aquaculture Engineering First Edition.

Leo-Moggie A. Keynote address(2002). Eighth APEC coal flow seminar/nineth APEC clean fossil energy technical seminar/fourth APEC coal trade investment liberalization and facilitation workshop. Kuala Lumpur, Malaysia; 2002.

Masaló Llorà, I. (2008). Hydrodynamic characterisation of aquaculture tanks and design criteria for improving self-cleaning properties. Universitat Politècnica de Catalunya.

Masuduzzaman, M. (2013). Electricity Consumption and Economic Growth in Bangladesh: Cointegration Analysis. Research Study Series No. - FDRS 02/2013.

Mondal, M. A. H., Denich, M., and Mezher, T. (2014). Deployment of renewable energy technologies in Bangladesh: Long-term policy implications in power sector. Energy Strategy Reviews, 2(3-4), 307-312. 
Moran, S. (2018). An Applied Guide to Water and Effluent Treatment Plant Design. Butterworth-Heinemann.

Neori, A., Chopin, T., Troell, M., Buschmann, A. H., Kraemer, G. P., Halling, C., and Yarish, C. (2004). Integrated aquaculture: rationale, evolution and state of the art emphasizing seaweed biofiltration in modern mariculture. Aquaculture, 231(14), 361-391.

Prado Jr, F. A., Athayde, S., Mossa, J., Bohlman, S., Leite, F., and Oliver-Smith, A. (2016). How much is enough? An integrated examination of energy security, economic growth and climate change related to hydropower expansion in Brazil. Renewable and Sustainable Energy Reviews, 53, 11321136.

Pimentel, D. (2008). Renewable and solar energy technologies: energy and environmental issues. In Biofuels, Solar and Wind as Renewable Energy Systems (pp. 1-17). Springer, Dordrecht.

Quispe, I., Navia, R., and Kahhat, R. (2017). Energy potential from rice husk through direct combustion and fast pyrolysis: a review. Waste management, 59, 200-210.

Rakob M.Y, - Planning for smart grid in TNB system,\| in Proc. IEEE Conference on Power and Energy Proceedings, Kuala Lumpur, 2010.

Rathour, R., Kalola, V., Johnson, J., Jain, K., Madamwar, D., and Desai, C. (2019). Treatment of Various Types of Wastewaters Using Microbial Fuel Cell Systems. In Microbial Electrochemical Technology (pp. 665-692). Elsevier.

RenewableEnergyAct2011,Law ofMalaysia,Act 725, 2011. www.seda.gov.my http://www. scirp.org/(S(i43dyn45teexjx455qlt3d2q))/ reference/References Papers.
aspx?ReferenceID $=682266$ Science + Business Media; 2008.

Shah, S., Venkatramanan, V., and Prasad, R. (2019). Microbial Fuel Cell: Sustainable Green Technology for Bioelectricity Generation and Wastewater Treatment. In Sustainable Green Technologies for Environmental Management (pp. 199-218). Springer, Singapore.

Skoglund A., Leijon M., Rehn A., Lindahl M., and Waters R. (2010) On the physics of power, energy and economics of renewable electric energy sources - Part II, Renewable Energy, 35, 1735-1740.

Sritram, P., Treedet, W., \& Suntivarakorn, R. (2015). Effect of turbine materials on power generation efficiency from free water vortex hydro power plant. In IOP Conference Series: Materials Science and Engineering (Vol. 103, No. 1, p. 012018). IOP Publishing.

Thank, W., Bruns, S., Burke, P., Day, C., Johansson, H., Pezzey, J.,and Kander, A. (2012). The Role of Energy in the Industrial Revolution and Modern Economic Growth. The Energy Journal, 33(3), 125-152. https://doi.org/10.5547/01956574.33.3.5

Trumbo, B. A., Ahmann, M. L., Renholds, J. F., Brown, R. S., Colotelo, A. H., and Deng, Z. D. (2014). Improving hydroturbine pressures to enhance salmon passage survival and recovery. Reviews in Fish Biology and Fisheries, 24(3), 955-965.

Walker, C. H., Sibly, R. M., Hopkin, S. P., and Peakall, B. (2012). Principles of ecotoxicology. CRC press.

Wang X, Feng YJ, Lee H( 2008). Electricity production from beer brewery wastewater using single chamber microbial fuel cell. Water Sci Technol,57(7):1117-1121. doi: 10.2166/wst.2008.064 
